\title{
TOO NEAR AND TOO FAR: AUSTRALIA'S RELUCTANCE TO NAME AND PROSECUTE GENOCIDE
}

\author{
Jennifer Balint ${ }^{1}$
}

\section{Introduction}

Another suspected war criminal found in Australia. In the Australian Capital Territory (ACT) Magistrates Court in late 2014, former Bosnian Croat soldier, Krunoslav Bonić, was the subject of an extradition hearing to face war crimes charges in Bosnia and Herzegovina. Apparently he had been living in Canberra since 1998, yet an international arrest warrant was issued by Bosnia only in 2006. This is not surprising. Australia's record on prosecuting war crimes, including genocide, is poor indeed. According to a Lowy Institute report, Australia was described in the Simon Wiesenthal Center's annual status report on Nazi war crimes investigations and prosecutions as "the only major Western country of refuge.”2 In January 2015, Bosnia dropped its extradition request and Bonić was freed. It is unclear why: serious allegations were made against Bonić by eyewitnesses in at least one case heard at the International Criminal Tribunal for the former Yugoslavia. ${ }^{3}$

Australia has an abysmal record in prosecuting genocide and state crime, perpetrated either here or elsewhere. There is something curious about Australia's reluctance to prosecute this crime. It is either too near (in the case of Indigenous genocide in Australia) or too far away (in the case of the Holocaust

1 I am grateful to Eleanor Gilbert who allowed me access to the files on the hearings in relation to the Aboriginal Embassy case, and to Evelyn Rose for her thoughtful research assistance on this chapter. My thanks to my Honours colleague at Macquarie University, Angela Jones, whose thesis, written in 1991 and supervised by Colin Tatz, provides an excellent overview of public debates at the time, something that has been lost in much subsequent analysis. Deep thanks to Colin Tatz, with whom I began this journey.

2 Fergus Hanson, Confronting Reality: Responding to War Criminals in Australia (Sydney: Lowy Institute for International Policy, 2009), 6.

3 International Criminal Tribunal for the Former Yugoslavia, Kordić \& Čerkez IT-95-14/2, case transcript, September 13, 1999, see 6510. After detailing the involvement of Bonić, together with his father, in the arrest and detention of the witness, Fuad Zeco, the transcript continues: Q. Thank you. Thank you. This Krunoslav Bonić who arrested you, did you know whether he was captured by the BH army during the conflict and where he now lives? A. Yes, he was captured. After the war conflict ceased, he was arrested. I know that he was arrested and that he spent his time in prison in Travnik, and after that, after a certain amount of time spent in prison, he moved to Australia. That's what I know. 
in World War Two, or genocide in Rwanda or in the former Yugoslavia). We ratified its Convention, decried in its defining into international law as an "odious scourge,"4 yet our political leaders have almost routinely disregarded the importance of prosecuting genocide. Taskforces have been set up and abandoned, downsized, and recommendations ignored. We have failed to name or hear the crime of genocide perpetrated against Aboriginal Peoples-and it was only with the hearing of the genocide charges brought by the Aboriginal Tent Embassy in 1998 that it was made public that, despite signing the Convention on the Prevention and Punishment of the Crime of Genocide (the "Genocide Convention”) in 1949, we had not in fact incorporated the crime of genocide into Australian domestic legislation.

This essay considers our record on addressing genocide and why we are so reluctant to prosecute. It suggests that in our refusal to acknowledge genocide, we maintain the charade of a country without history. We are, in many ways, a land of forgetting. This reluctance to prosecute "the past" is integral to this enterprise. That the past informs the present, however, is what is inherently risky about this apparently entrenched policy approach to an aversion to the naming and prosecuting of genocide.

\section{Too far away: Australia's record on prosecuting World War Two crimes}

In the 1980s, Australia introduced legislation to prosecute perpetrators from the Second World War who were current Australian citizens or residents. This was the first time that a domestic legislative framework was established to prosecute World War Two perpetrators who had sought refuge and asylum in post-war Australia. The Hawke Labor government amended the War Crimes Act 1945 to allow charges to be brought against suspected war criminals living in Australia.

The War Crimes Act had been legislated post-war to enable the prosecution of 807 Japanese defendants, for crimes mostly perpetrated against Australian soldiers. ${ }^{5}$ This was, it has been argued, fuelled by deep-seated racist underpinnings of Australian attitudes towards the Japanese existing prior to the Second World War with its "White Australia” policy, and by the witnessing by the Australian population of Australian prisoners of war returning home

\footnotetext{
4 United Nations, Convention on the Prevention and Punishment of the Crime of Genocide (1948), Preamble.

5 Helen Durham and Michael Carrel, "Lessons from the Past: Australia’s Experience in War Crimes Prosecution and the Problem of the Applicable Legal Framework," Asia-Pacific Yearbook of International Humanitarian Law 2 (2006), 135.
} 
after horrific experiences in Japanese camps. ${ }^{6}$ Military trials were held in the Asia-Pacific region and in Australia, with 579 individuals convicted and 137 sentenced to death and executed. ${ }^{7}$ The War Crimes Act, however, was designed to prosecute crimes solely against British citizens or subjects. It had no remit for enabling the broader prosecution of crimes perpetrated in World War Two, or in other conflicts. The witnessing of POW experiences did not extend to the experiences suffered by post-war European refugees. That harm was not visible to the broader Australian population.

There had been little public or political appetite for broader post-war prosecutions. In 1961, the Acting Minister for External Affairs, Sir Garfield Barwick announced-in response to refusing a request from the Soviet Union for extradition of an alleged war criminal, Ervin Richard Adolf Petrovich Viks - the end of war crimes prosecutions under Australian legislation. He argued that whilst there is a sense of "utter abhorrence felt by Australians for those offences against humanity to which we give the generic name of war crimes ... there is the right of this nation, by receiving people into its country, to enable men to turn their backs on past bitterness and to make a new life for themselves and for their families in a happier community."8 Barwick concluded in this vein: “. . . we think the time has come to close the chapter. It is, truly, the year 1961." "This came from someone who three years later was to become Chief Justice of the High Court of Australia. The policy of forgetting was entrenched. Even the Japanese war crimes trials had been seen to take too long. In 1950, with the announcement by the Menzies government to speed up trials, release those with insufficient evidence, and reserve the right to make a re-arrest if new material surfaced, then leader of the opposition Mr Chifley, stated: "I could not see much purpose in continuing investigations aimed at the tracing of war criminals. That sort of thing could go on for the next 20 years, and new criminals could be located almost daily."

As a result of the investigative work by journalist Mark Aarons, the extent of the settlement in Australia of suspected war criminals became known. ${ }^{11}$

6 Michael Carrel, “Australia’s Prosecution of Japanese War Criminals: Stimuli and Constraints,” in The Legacy of Nuremberg: Civilising Influence or Institutionalised Vengeance?, eds. David Blumenthal and Timothy McCormack (Boston: Martinus Nijhoff Publishers, 2007), 240-42; also see Gideon Boas and Pascale Chifflet, “Suspected War Criminal in Australia: Law and Policy,” Melbourne University Law Review 40 (2016), 48-49.

7 Carrel, Ibid., 246-47.

8 The Hon. Sir Garfield Barwick, Press Statement on Soviet Request for Surrender of E.R.A.P. Viks (Canberra: Commonwealth of Australia Department of External Affairs, 1961), 7.

9 Ibid.

10 Andrew Menzies, Review of Material Relating to the Entry of Suspected War Criminals Into Australia (Canberra: Australian Government Publishing Service, 1987), 10.

11 Mark Aarons' five-part documentary series Nazis in Australia was broadcast on ABC Radio National in 
Much of this had begun as anecdotal-Jewish refugees sharing boats to Australia with Nazi perpetrators-and had been documented immediately postwar by the Jewish community, together with Aarons' own extensive archival work. $^{12}$ Later work demonstrated that this was a deliberate policy of excluding Jewish Displaced Persons and accepting those predominantly from the Baltic countries. ${ }^{13}$ Early in 1986, the Executive Council of Australian Jewry had begun lobbying the Australian government for an enquiry, similar to that undertaken in Canada. ${ }^{14}$ In June 1986 the Hawke Government appointed a retired senior public servant, Andrew Menzies, to conduct a review of material relating to the entry of suspected war criminals into Australia. Menzies found that it was "more likely than not that a significant number of persons who committed serious war crimes in World War Two entered Australia and some of these are now in Australia," and "that some action needs to be taken."15 He recommended a special unit be established to investigate the allegations and initiate extradition, deportations or prosecutions. ${ }^{16}$ His first recommendation to the government was that they "make a clear and positive statement to the effect that, as regards serious war crimes, it does not regard the Chapter as closed (contrary to the Barwick statement in 1961) and that it will take appropriate action under the law to bring to justice persons who have committed serious war crimes found in Australia."17

The government's response to that review was tabled in Parliament on February 24, 1987, by Senator Gareth Evans on behalf of the Attorney-General Lionel Bowen. It read in part:

The Government accepts the conclusion that some persons, against whom the most serious allegations have been made, are likely to have entered Australia after the Second World War, and to be still resident here today.

1986. This was the culmination of earlier documentaries and work that had begun in 1977 . He subsequently published a book detailing the allegations: Mark Aarons, Sanctuary: Nazi Fugitives in Australia (Melbourne: William Heinemann Australia, 1989).

12 Both Aarons and Suzanne Rutland tell how in the early 1950s, the Federal Immigration Minister, Harold Holt, threatened Jewish community leaders that if they did not stop their campaign against the migration to Australia of known Nazis, the government would block the transfer of money to Israel by the community. See Mark Aarons, "The Search For Nazi War Criminals in Australia,” Australian Journal of Jewish Studies 26 (2012), 164-65; Suzanne Rutland, Edge of the Diaspora: Two Centuries of Jewish Settlement in Australia (Sydney: Collins, 1988), 334-35.

13 Leslie Caplan, The Road to the Menzies Inquiry: Suspected War Criminals in Australia (Darlington: Australian Jewish Historical Society, 2012), Appendix 3.

14 Ibid.

15 Menzies, Review of Material, 125.

16 Ibid., 168.

17 Ibid., 169. 
However, as Mr Menzies has found, their entry was achieved in the circumstances of the urgency and intensity of our post-war immigration program. Given that background, there is no value in continuing to examine the past with the idea of apportioning blame, or endeavouring to sheet home responsibility. Instead, our attention must be concentrated on the steps to be taken to ensure that suspected war criminals involved in serious crimes are brought to justice. ${ }^{18}$

Drawing a line under Barwick's statement, the response continued: "Where serious War crimes are concerned this Government does not regard the chapter as closed." ${ }^{19}$ This enthusiasm was, however, short lived. Public appetite, and hence political appetite, for war crimes trials continued to be limited. The Bill took 14 months to pass both the House of Representatives and the Senate, with the War Crimes Amendment Act eventually becoming law on December 21, 1988, after divisive political debate. ${ }^{20}$ The new law was still contained to World War Two era crimes and the government failed to specifically name genocide. Rather, war crimes were defined to include genocide as "intent to destroy":

A serious crime is a war crime if it was: (a) committed: (i) in the course of political, racial or religious persecution; or (ii) with intent to destroy in whole or in part a national, ethnic, racial or religious group, as such; and (b) committed in the territory of a country when the country was involved in a war or when territory of the country was subject to an occupation. ${ }^{21}$

As a "war crime," genocide was subsumed under the category of "bad things happen in wartime" (in Europe), rather than the perpetration of the destruction of a people and of their common humanity. Like the International Military Tribunal at Nuremberg, it also continued a curtailed mandate, using September 1, 1939, as the start date, thereby omitting much of the criminal activity perpetrated prior to that date.

The War Crimes Amendment Act 1988 led to the establishment of a Special Investigation Unit within the Department of Public Prosecutions that examined allegations of war crimes against over 800 individuals resident in

18 Senator Gareth Evans, Government Response to Menzies Review (Canberra: Parliament of Australia Senate, 1987), 496.

19 Ibid.

20 Irene Nemes, "Punishing War Criminals in Australia: Issues of Law and Morality," Current Issues in Criminal Justice 4, no. 2 (1992), 142-43.

21 War Crimes Amendment Act 1988, part 2, sec 6.1. 
Australia. Evidence was found against 400 people who had arrived in Australia; of these, 200 were deceased. There was evidence for 40 prosecutable cases, and four were initially pursued. ${ }^{22}$ There had been great hope in this new legislation, as echoed in its preamble:

(a) concern has arisen that a significant number of persons who committed serious war crimes in Europe during World War II may since have entered Australia and became Australian citizens or residents;

(b) it is appropriate that persons accused of such war crimes be brought to trial in the ordinary criminal courts in Australia; and

(c) it is also essential in the interests of justice that persons so accused be given a fair trial with all the safeguards for accused persons in trials in those courts, having particular regard to matters such as the gravity of the allegations and the lapse of time since the alleged crimes. ${ }^{23}$

Yet, due to a combination of ill health and the advancing age of the defendants and, critically, the compounding difficulties of processing European war crimes cases in local courts in Adelaide, none were found guilty.

In the first case, Ivan Polyukhovich was charged in January 1990 with the killing of 24 Ukrainian Jews and involvement in the murder of a further 850 Ukrainian Jews between 1941 and 1943. After an appeal to the High Court on the basis of the legislation being unconstitutional (that was quashed), he was committed to trial in the Supreme Court of South Australia and, due to insufficient witness testimony, the trial ceased. ${ }^{24}$ The second case was that of Mikolay Berezowsky. He was charged in 1991 with involvement in the murder of 102 Jews in Ukraine. Despite the hearing of 22 international witnesses, the case was dismissed in July 1992 by the magistrate during the committal hearings due to "identification difficulties." 25 In the third case of Heinrich Wagner, charges were brought in 1992 for the murder of 19 Jewish children and a railway construction worker, and involvement in the murder of 104 Ukrainian Jews in 1942 and 1943. The magistrate found sufficient evidence to commit to trial, yet prosecutors discontinued the case due to illness after Wagner suffered

22 War Crimes Amendment Act 1988 (Cth), Preamble.

23 According to Graham Blewitt, Head of the Special Investigations Unit, the extent of the Australian trials was to be 12. Cited in Angela Jones, More Than a Memory: Australia's War Crimes Trials (Honours thesis, Macquarie University, 1991), 75.

24 For further detail, see Gillian Triggs, “Australia's War Crimes Trials: All Pity Choked,” in The Law of War Crimes: National and International Approaches, eds. Timothy McCormack and Gerry Simpson (The Hague: Kluwer Law International, 1997), 123-49 and, in particular, 130-32.

25 For further detail, see Ibid., 132. 
a heart attack. ${ }^{26}$ There was a fourth case about to be brought; however, with the disbanding of the Special Investigation Unit by the Keating Government, this did not eventuate.

There had been little public interest in these trials. From a high point of bipartisanship when the legislation was first introduced by the Hawke Labor government in late 1987, this had deteriorated to the legislation passing in the Senate a year later by just five votes. The political atmosphere had changed. There were heated public debates around questions of money, the age of defendants (although as Angela Jones pointed out in her analysis of the trials at the time, there was no such objection raised when 80-year-old Queensland Premier Joh Bjelke-Petersen stood trial for perjury in October $1991^{27}$ ), the time that had passed, that the courts would be relying on evidence from communist countries, ${ }^{28}$ as well as concern from particular communities who shared the same national background as the suspects. There was a sense, as expressed by Labor Senator Bernard Cooney in the Senate debate on the Bill, that "bygones be bygones." ${ }^{29}$ What appeared to be missing, as Jones points out, was a sense of what these trials were attempting to prosecute: the crimes of the Holocaust. ${ }^{30}$

The unit closed in 1992. Since then, there have been only limited resources put towards the prosecution of Nazi war criminals, ${ }^{31}$ and no prosecutions have been brought. One emerging frontier has been that of extraditions sought by other nations, mainly post-communist, for the trial of war criminals suspected to be residing in Australia. Australia has been reluctant to take this path: in a discussion of the extradition proceedings of suspected Hungarian war criminal Károly Zentai, Ruth Balint has argued that any recognition of war criminals living in Australia disrupts "the popular imaginary of the post-war period of immigration [that] has privileged a narrative of rescue of Hitler's and Stalin's victims." ${ }^{32}$ Harbouring of perpetrators plays no role here.

It was a case outlining past and present genocide in Australia that brought,

\footnotetext{
26 For further detail, see Triggs, “Australia’s War Crimes,” 133-34.

27 Angela Jones, More Than a Memory: Australia's War Crimes Trials (Honours thesis, Macquarie University, 1991), 62.

28 For discussion of this point, see Nemes, "Punishing War Criminals," 143-45.

29 Hansard Senate War Crimes Amendment Bill 1987, $2^{\text {nd }}$ reading, December 15, 1987, 4254, cited in Jones, More Than a Memory, 67.

30 Ibid., 56.

31 As Gideon Boas and Pascale Chifflet note, "responsibility for the investigation of such crimes has been delegated to various departments within the Australian Federal Police," and "Since the Menzies Review, there has been no large-scale or commissioned investigation into the entry of suspected war criminals into Australia."

32 Ruth Balint, "The Ties that Bind: Australia, Hungary and the Case of Károly Zentai," Patterns of Prejudice 44, no. 3 (2010), 284.
} 
if not to the public but to the legislature, attention of our failure to prosecute the crime of genocide in this country.

\section{Too near: the Aboriginal Tent Embassy genocide hearings}

In the late 1990s, members of the Aboriginal Embassy tested the ability of our courts to hear genocide. The Embassy had been established in 1972 as a land rights protest on the grounds of what is now Old Parliament House, and has continued to serve as a focal point of protest. ${ }^{33}$ On July 3, 1998, Wadjularbinna Nulyarimma, of Doomadgee Aboriginal Community in Queensland, lawyer Len Lindon, and Eleanor Gilbert who recorded much of the proceedings, went to the Canberra police station to request that charges of genocide be brought against current Members of the Australian Parliament. The amendments to the Native Title Act were being debated in the Australian Parliament. The Native Title Amendment Bill 1997 was the latest iteration of the legislative regime established in 1993 to regulate Aboriginal land claims. Developed in the wake of the successful Mabo High Court decision in which the Court ruled in 1992 that Australia was not terra nullius ("land belonging to no-one") on settlement/invasion, it had developed into a restrictive regime of access to land known as "native title."

The claim made by the Embassy was that the imminent introduction of the revised Native Title Act put Aboriginal peoples at even greater risk of destruction and was part of a long history of genocidal practices. ${ }^{34}$ In May 1997, then Prime Minister John Howard had introduced into policy a "10-point plan" in response to the High Court ruling on the Wik case. ${ }^{35}$ The High Court in Wik found that pastoral leases did not automatically extinguish native title. Howard argued, "The fact is that the Wik decision pushed the pendulum too far in the

33 For more information on the Aboriginal Embassy, see Gary Foley, Andrew Schaap and Edwina Howell, eds., The Aboriginal Tent Embassy. Sovereignty, Black Power, Land Rights and the State (Abingdon: Routledge, 2014).

34 Damien Short has argued that genocide is a "continuing process in an Australia that has failed to decolonise and continues to assimilate," is "predicated on a victim's understanding of the culturally genocidal dimensions of settler colonialism and the central importance of land to the survival of many indigenous peoples as peoples." See Damien Short, “Australia: A Continuing Genocide?” Journal of Genocide Research 12, no. 2 (2010), 46. For further relevant discussion, see Colin Tatz, "Genocide in Australia," Journal of Genocide Research 1, no. 3 (1999), 315-52; Colin Tatz, “Confronting Australian Genocide,” Aboriginal History 25, no. 1 (2001), 16-36; Katherine Bischoping, and Natalie Fingerhut, "Border Lines: Indigenous People in Genocide Studies," Canadian Review of Sociology 33, no. 4 (1996), 481-506; Larissa Behrendt, “Genocide: The Distance Between Law and Life,” Aboriginal History 25 (2001), 132-47; Patrick Wolfe, "Nation and Miscegenation: Discursive Continuity in the Post-Mabo Era," Social Analysis 36 (1994), 93-131; Patrick Wolfe, "Settler Colonialism and the Elimination of the Native,” Journal of Genocide Research 8, no. 4 (2006), 387-409.

35 Wik Peoples v Queensland (1996-187 CLR 1). This was a successful native title claim on land on the Cape York Peninsula brought by the Wik and Thayorre People. 
Aboriginal direction. The 10-point plan will return the pendulum to the centre." ${ }^{36}$ The subsequent Native Title Amendment Act 1998 had at its core the extinguishment of native title (as outlined in its originating Bill):

States and Territories would be able to confirm that "exclusive" tenures such as freehold, residential, commercial and public works in existence on or before 1 January 1994 extinguish native title. Agricultural leases would also be covered to the extent that it can reasonably be said that by reason of the grant or the nature of the permitted use of the land, exclusive possession must have been intended. Any current or former pastoral lease conferring exclusive possession would also be included. ${ }^{37}$

The United Nations Committee on the Elimination of All Forms of Racial Discrimination was to call this a racially discriminatory piece of legislation on the basis that, as Damien Short points out, it "detail[s] a host of white property interests that would automatically extinguish native title." ${ }^{\text {, It }}$ It was put to the Court that the native title legislation demonstrated "intent to destroy" as required by the Genocide Convention that Australia had ratified, although not implemented. On July 6, 1998, papers and an affidavit by central claimant Wadjularbinna Nulyarimma were presented to the Registrar of the ACT Magistrate's Court, asking that John Howard and Tim Fischer (as Prime Minister and Deputy Prime Minister) be charged with attempt, conspiracy and complicity in genocide (in their formulation of the "10-point plan" and enactment into legislation), Brian Harradine (Independent Member of the Senate) be charged with complicity in genocide (in his agreeing to the Native Title Amendment Bill), and Pauline Hanson (MP and leader of the One Nation party) be charged with public incitement to commit genocide (that over the past two years she had deliberately and publicly incited genocide). The Registrar of the ACT Magistrate's Court replied to the Embassy claimants: "I have come to the conclusion that the offences alleged [genocide, attempted genocide, aid and abet genocide, conspiracy to commit acts of genocide] in those informations are unknown to the law of the ACT."39

The hearing took place over seven days from July to September 1998, including one morning "around the fire" at the Embassy where Justice Crispin

36 John Howard, “Amended Wik 10-Point Plan,” media statement, May 8, 1997, http://australianpolitics.com/ 1997/05/08/howard-amended-wik-10-point-plan.html.

37 Native Title Amendment Bill 1997 Explanatory Memorandum, Parliament of the Commonwealth of Australia, http://www.austlii.edu.au/au/legis/cth/ bill_em/ntab1997237/memo2.html, chap. 2.2.

38 Short, “Australia,” 55.

39 Letter from PR Thompson, Registrar ACT Magistrates Court, to Mrs W. Nulyarimma, July 7, 1998. 
heard testimony. ${ }^{40}$ Affidavits were gathered and presented to the court from communities around Australia. The case was joined by Tom Trevorrow, Irene Watson, Kevin Buzzacott and Michael Anderson, Alice Hoolihan, Daisy Brown, Albert Hayes, Alister Thorpe, Yaluritja Clarrie Isaacs and Mingli Wanjurri Nungala. The claimants spoke to the reality that Australia had not recognised the genocide perpetrated here. They gave testimony that detailed their own and their community's experiences of genocide, both past and continuing. Wadjularbinna stated in an affidavit:

The applicants' main concern is that the genocide against our people all Aboriginal peoples be stopped and prevented. We invoke your criminal law primarily to get your people to stop the genocide [par. 10]. . . . We see the Parliamentarians failure to prevent genocide against us by legislation or otherwise as another act of genocide [par.17].... We have had enough of this genocide. This is a crisis situation and irreparable damage is being done [par. 35]. ${ }^{41}$

There was a clear sense in the claims put forward in the case that there was continuing intent to perpetrate genocide in Australia, illustrated by the failure to integrate the Genocide Convention into domestic legislation and the use of law in fact to perpetuate genocide. ${ }^{42}$ Wadjularbinna testified:

Australia has ratified the Convention but they have not backed it up by making laws to prevent further genocide ... speaks volumes ... . there is an ongoing intent ... to continue the genocide. ${ }^{43}$

Justice Crispin did not find for the applicants from the Tent Embassy. He argued that members of Parliament could not be liable for criminal prosecution in the carrying out of their duties and in the formulation of policy. He also argued that he could not find within the common law any recognition of the offence of genocide, stating that "no offence of genocide is known to the

40 For a detailed discussion of the case, see Jennifer Balint, "Stating Genocide in Law: The Aboriginal Embassy and the ACT Supreme Court," in The Aboriginal Tent Embassy: Sovereignty, Black Power, Land Rights and the State, eds. Gary Foley, Andrew Schaap and Edwina Howell (Abingdon: Routledge, 2014), 235-50.

41 Affidavit of Wadjularbinna Nulyarimma, July 8, 1998.

42 For a broader discussion of the use of law in the perpetration of genocide and how law can make genocide 'allowable', see Jennifer Balint, Genocide, State Crime and the Law: In the Name of the State (London: Routledge-Cavendish, 2012), in particular Chapter Two.

43 Wadjularbinna, Tent Embassy case transcript, 77. 
domestic law of Australia." ${ }^{44}$ But he did find that genocide had occurred. Following a discussion of the Genocide Convention, he stated:

There can be little doubt that the shameful chronicle of abuse suffered by aboriginal peoples in Australia since 1788 included many acts of the kind described in this definition. Given the passage of time, the paucity of contemporary records and the inevitable tendency for people to indulge in self justification it is not easy to determine whether particular atrocities were committed with the requisite intent. Nonetheless, the nature, scope and frequency of such acts suggests at least a strong probability that some at least were so motivated. In 1983 Murphy J referred to the Aboriginal people of Australia as having been the subject of "attempted genocide." However, the concept of genocide contained in Article 2 of the Convention does not require that the relevant "national, ethnical, racial or religious group" be destroyed, but only that one or more of the specified acts be committed with the intention of destroying the group "in whole or in part." Many of the atrocities plainly satisfied this description. In 1989 J.H.Wootten QC expressed the view that assimilation in its crudest forms, and particularly the removal of aboriginal children, fell within this definition. For present purposes, it is unnecessary for me to determine whether the particular conduct to which he referred would have been sufficient to sustain charges of genocide if such an offence formed part of the domestic law of Australia. There is ample evidence to satisfy me that acts of genocide were committed during the colonisation of Australia. ${ }^{45}$

This was a significant statement as it was the first time in Australian law that genocide against Indigenous Peoples had been so clearly recognised. Further, the case and its appeal prompted realisation that while Australia had signed the Genocide Convention, it had failed to integrate it into domestic legislation. While Australia was amongst the first to sign the Genocide Convention (on the day it was opened for signature, December 11, 1948), and ratified it in 1949, it subsequently failed to introduce legislation that would enable its domestic prosecution. On the one hand, this was not surprising. Those debating the ratification of the Convention in 1949 were convinced that it could never happen here. As Colin Tatz relates, in some 19 pages of the June 1949 parliamentary debate on Australia's ratification of the Convention, Aborigines were not mentioned. ${ }^{46}$ Archie Cameron, Liberal Member for Barker argued in Parliament: 
No one in his right senses believes that the Commonwealth of Australia will be called before the bar of public opinion, if there is such a thing, and asked to answer for any of the things which are enumerated in this convention. $^{47}$

That Australia and Australians could be capable of genocide, past or present, was unthinkable. Little has changed, although the academic consensus now acknowledges that genocide is an apt descriptor for the Australian Aboriginal experience, and that the "intent to destroy" required to establish the crime of genocide need not be malevolent - that the effect of destruction remains the same. ${ }^{48}$ Yet Australia had failed to introduce legislation to enable genocide to be prosecuted in Australia.

There had been no space in law previously to hear these claims of genocide. In his 2008 apology, then Prime Minister Kevin Rudd spoke of indignity, degradation, mistreatment, but not genocide. ${ }^{49}$ The Bringing Them Home Report named genocide, but its recommendations, including a national compensation mechanism, failed to be implemented. ${ }^{50}$ Cases have unsuccessfully been brought attempting to have genocide put on record-at least indirectly. ${ }^{51}$ There had been fleeting recognition of genocide earlier, where in Coe v Commonwealth 1979 in the Australian High Court, Justice Murphy noted: “the

46 Colin Tatz, With Intent to Destroy: Reflecting on Genocide (New York: Verso, 2003), 69.

47 Archie Cameron, cited in Ibid., 67.

48 Tatz, With Intent, 98-99.

49 Kevin Rudd, “Apology to Australia’s Indigenous Peoples,” Parliamentary Debates (Canberra: House of Representatives, Parliament of Australia, 2008), 167-77.

50 See Andrea Durbach, "Repairing the Damage: Achieving Reparations for the Stolen Generations," Alternative Law Journal 27, no. 6 (2002), 262-66.

51 See Chris Cunneen and Julia Grix, The Limitations of Litigation in Stolen Generations Cases (Canberra: Australian Institute of Aboriginal and Torres Strait Islander Studies, 2004); also see Ann Curthoys, Ann Genovese and Alex Reilly, Rights and Redemption: History, Law and Indigenous People (Sydney: University of New South Wales Press, 2008). Most of the cases have been based on breaches of duty of care, wrongful imprisonment, and the consequences of child removal. Where genocide has been put to the courts, it has been on the whole rejected. For example, in Kruger $v$ The Commonwealth of Australia (1997-190 CLR 1), the judges expressly noted that the Aboriginals Ordinance 1918, which authorised the removal (between 1925 and 1944) of the nine children who brought the case, did not authorise acts of "genocide" as defined in the Genocide Convention. As Chris Cunneen and Julia Grix note on page 27: “Government records are likely to paint a picture in which the removal and subsequent treatment of Indigenous children complied with 'their best interests' and met the standards of the time. Protection laws are characterised as benign in their intent, as 'beneficial' laws - even if discriminatory. Under these circumstances, the likelihood that the forced removal of Indigenous children will be considered by the courts as constituting genocide is remote.” One case that has been successful is that of Bruce Trevorrow, taken from his family at the age of 13 months from hospital by the Aboriginal Protection Board and placed in a non-Indigenous foster family for the next 10 years. In Trevorrow $v$ State of South Australia (No. 5) (2007-SASC 285), his removal was found to be unlawful and he was awarded \$525,000 in compensation. South Australia, alongside Tasmania and most recently NSW, has now instituted a Stolen Generations reparations scheme. 
aborigines did not give up their lands peacefully; they were killed or removed forcibly from the lands by United Kingdom forces or the European colonists in what amounted to attempted (and in Tasmania almost complete) genocide." 52 These are rare moments. No justice space has been created of acknowledgement, recognition and redress; rather a policy of " reconciliation" has been the policy approach taken by successive governments.

The case and its appeal prompted the bringing of a Private Senator's Bill, the Anti-Genocide Bill 1999 (Cth) by Australian Democrat Senator Brian Greig, who, in his second reading speech "referred to the prevention and punishment of the crime of genocide as 'unfinished business' of the Commonwealth Parliament."53 The Bill was referred by the Senate to the Legal and Constitutional Affairs References Committee, whose June 2000 report found that "anti-genocide legislation in Australia was both necessary and timely, and recommended that the Bill be referred to the Attorney General for consideration of the matters identified by the Committee in respect of its contents." 54

The Bill was overtaken by the ratification of the International Criminal Court Statute by Australia. In 2002, as a result of pressure from other signatories to the International Criminal Court, Australia introduced the International Criminal Court (Consequential Amendments) Act 2002. A key principle of the Statute of the new International Criminal Court, which holds jurisdiction to hear crimes of genocide, war crimes, and crimes against humanity, was that it would not usurp genuine national attempts to try these crimes. The "principle of complementarity" means that the Court will only take the case if the state where the crime was perpetrated is unwilling or genuinely unable to do so. ${ }^{55}$ This meant that Australia is obliged to implement legislation to enable prosecution even if, as Gillian Triggs has noted, "The existence of such laws by no means indicates the extent of their enforcement. Indeed, Australian practice suggests that war crimes prosecutions have ultimately depended upon political will." 56 This is reflected in the "Declaration" that Australia included in its last-minute signature, reinforcing "the primacy of its criminal jurisdiction" and that the Attorney-General must authorise any arrest or extradition to the

\footnotetext{
52 Coe v Commonwealth 1979 HCA 68, par. 8.

53 Shirley Scott, "Why Wasn't Genocide a Crime in Australia? Accounting For the Half-century Delay in Australia Implementing the Genocide Convention,” Australian Journal of Human Rights 10, no. 2 (2004): article 22, n.p.

54 Senate Legal and Constitutional Committee 2000 cited in Ibid., n.p.

55 The Preamble notes that "the International Criminal Court established under this Statute shall be complementary to national criminal jurisdictions" and this is reiterated in Article 17 of the Rome Statute.

56 Gillian Triggs, "Implementation of the Rome Statute for the International Criminal Court: A Quiet Revolution in Australian Law,” Sydney Law Review 25, no. 4 (2003), 518.
} 
Court. ${ }^{57}$ Much of this was for Australian public consumption rather than for the purposes of operation of the Court. ${ }^{58}$

The approach taken, as Triggs has outlined, was to amend the Australian Criminal Code Act 2005 by creating a new Chapter 8- “Offences Against Humanity and Related Offences."59 In relation to genocide, five new offences of genocide were added to the Criminal Code, that incorporate the definition of genocide in the ICC's Elements of Crimes that had been drafted by the Preparatory Commission of the Court (and are taken from the Genocide Convention). These are: 268.3 Genocide by killing; 268.4 Genocide by causing serious bodily or mental harm; 268.5 Genocide by deliberately inflicting conditions of life calculated to bring about physical destruction; 268.6 Genocide by imposing measures intended to prevent births; 268.7 Genocide by forcibly transferring children. ${ }^{60}$

Yet while genocide has become a criminal offence in Australia, and is now prosecutable - and indeed, named - it is up to the Attorney General to bring prosecutions, with the decision final and no challenges allowed. This has had the effect of Australia continuing to fail to prosecute genocide.

\section{"Closing the chapter" again?}

In his foreword to the Review of Material Relating to the Entry of Suspected War Criminals into Australia, Andrew Menzies wrote that "In the case of such crimes, the argument that the culprits, by coming to this country, have turned their back on such events has, in my view, no validity." ${ }^{11}$ Yet in Australian policy and practice today, we see a selective application of this approach. While "foreign fighters" legislation gets rushed through, we have no such equivalent scrutiny of the crimes perpetrated in genocide and other state crime internationally — or nationally. The provision of the Attorney-General to veto any prosecutions, means that it is in the hands of the government to determine prosecution of genocide.

This was evident with the halting of the investigation by the Melbourne Magistrates’ Court into the indictment filed by Arunachalam Jegatheeswaran,

57 Much of the declaration is concerned with Australia having primary jurisdiction over crimes, which is reflected in any case in the core principle of the Court of "complementarity.” See https://treaties.un.org/doc/ source/training/regional/2009/13-17October-2009/reservations-declarations-questions.pdf.

58 Alex Bellamy and Marianne Hanson, "Justice Beyond Borders? Australia and the International Criminal Court,” Australian Journal of International Affairs 56, no. 3 (2002), 417-33.

59 Triggs, "Implementation," 520.

60 International Criminal Court (Consequential Amendments) Act 2002 (Commonwealth of Australia), https://www.legislation.gov.au/Details/C2004A00993.

61 Menzies, Review of Material, 12. 
an Australian citizen, against Sri Lankan President Mahinda Rajapaska (who was about to visit Perth to attend the Commonwealth Heads of Government Meeting) on charges of war crimes and crimes against humanity. In a media conference, Jegatheeswaran stated: “He's [Rajapaksa] the commander-inchief and nothing would have happened without his knowledge or his directions, and ultimately, he should be answerable to what was happening." Slated for hearing on November 29, after having been filed late October 2011 under Division 268 of the Criminal Code Act 1995, the then Attorney-General Robert McClelland refused to support the matter, thus effectively ending the investigation.

Two years later, then Prime Minister Tony Abbott, in speaking on the issue of alleged war crimes committed during Sri Lanka's civil war and on persistent human rights concerns under the Rajapaksa government, stated that while his government "deplores the use of torture we accept that sometimes in difficult circumstances difficult things happen." 63 Meanwhile, countries such as Canada and the Netherlands have routinely been hearing charges of genocide, most recently in relation to the genocide in Rwanda. Yet in Australia, our response is that we must "move on." On the appointment of Indonesia's new security minister Wiranto, a former general who was indicted for crimes against humanity by the United Nations-established Serious Crimes Unit in Timor-Leste, the Australian Federal Justice Minister Michael Keenan responded that "we in government need to pursue what is in Australia's national interest in 2016." ${ }^{\prime 64}$ In 1993, with the recognition of at least one former Khmer Rouge official living in Australia who was identified as responsible for the torture and killing of Cambodians in "Democratic Kampuchea," the Cambodian Advisory Council of Australia requested amendments to the War Crimes Act so that prosecution could occur here. As Mark Aarons relates, nothing was done. ${ }^{65}$

62 Arunachalam Jegatheeswaran, cited in "Rajapaksa Indicated for War Crimes in Australian Court,” Tamil Guardian, October 23, 2011, http://www.tamilguardian.com/content/rajapaksa-indicted-war-crimes-australiancourt?articleid=3754.

63 Tony Abbott cited in Amanda Hodge, “ 'Difficult Things Happen’: Tony Abbott Defends Sri Lanka,” Australian, November 16, 2013, http://www.theaustralian.com.au/national-affairs/difficult-things-happen-tonyabbott-defends-sri-lanka/news-story/e1bac24a820d0b817bacd250eb18cd73.

64 Michael Keenan cited in Jewel Topsfield, “Alleged Timor War Crimes Forgotten as Ministers Fly in for Bali Terror Summit,” Sydney Morning Herald, August 10, 2016, http://www.smh.com.au/world/alleged-timorwar-crimes-forgotten-as-ministers-fly-in-for-bali-terror-summit-20160809-gqokk8.html. Wiranto had been the Defence Minister and Commander of Indonesian Armed Forces and was charged with "command responsibility for murder, deportation and persecution committed in the context of a widespread and systematic attack on the civilian population in East Timor." See "Timor-Leste Court Issues Warrant for Former Indonesian Defence Minister,” UN News Centre, May 10, 2004, http://www.un.org/apps/news/story.asp?NewsID=10677.

65 Mark Aarons, War Criminals Welcome: Australia, A Sanctuary or Fugitive War Criminals since 1945 (Melbourne: Black Inc., 2001), 40. 
Aarons' investigative work, alongside others, has shown, as he notes, that "it is a statistical certainty that Australia has war criminals, torturers and mass killers from almost every major killing field of the past half-century." have been allegations made by members of the Chilean, Cambodian, Afghani, Bosnian, and Rwandan communities, among others, about perpetrators who now live here. ${ }^{67}$ Victims have run into perpetrators at community centres, after years of refuge. ${ }^{68}$ Most recently, the issue has been raised of returning ISIS fighters being held responsible for the genocide against the Yazidi people in Northern Iraq. ${ }^{69}$

Genocide is not seen as worthy of trial in Australia. We can understand the three war crimes hearings held in the early 1990s as an anomaly. Barwick's claims, that Australia must be "history-less," are a more accurate reflection of where Australia stands. Tony Barta has argued that as beneficiaries of genocide, Australians cannot address it-as to do so is to acknowledge what we have gained. ${ }^{70}$ We can understand this is a form of denial, which Tatz and Winton Higgins identify as integral to genocide. ${ }^{71}$ As a "history-less" country that does not acknowledge its own history, we cannot acknowledge others. In denying our own history as settler-colonial, based on genocide, we also must deny others their history - as victims or perpetrators or bystanders - of conflicts elsewhere.

Irene Nemes, in her commentary on the closure of the Special Investigations Unit in the early 1990s, noted that "By abandoning the investigations, the government is allowing Nazi war criminals to remain complacent and protected from their past."72 We could add to this, that Australia remains protected

\footnotetext{
66 Ibid., 47.

67 Ibid. See chapters One and Two for an account of allegations and sightings of various perpetrators.

68 Ibid., chap. Two.

69 Nikki Marczak, “Comment: Seeking Justice For an Ongoing Genocide,” SBS News, August 22, 2016, http://www.sbs.com.au/news/article/2016/08/22/comment-seeking-justice-ongoing-genocide.

70 Tony Barta, “After the Holocaust: Consciousness of Genocide in Australia,” Australian Journal of Politics and History 31, no. 1 (1985), 154-61, see 160. "In Australia, where all of us are the beneficiaries of crimes against the Aborigines, the question can’t seriously penetrate our ideological defences. Anyone interested in the continued hegemony of our social values - property acquisition at the very centre of them - has a kind of functional incredulousness: how could our kind of society be criminal?” Barta continues: "Consciousness of genocide will have political implications, too. Anyone who knows what took place in this country must surely know what has to happen now.” While I disagree with Barta's assessment of Germany's citizens not having "gained" from the removal of the Jewish population, his assessment of Australia, and why we have failed to recognise the genocidal foundations of this society, is spot on. In Colin Tatz and Winton Higgins, The Magnitude of Genocide (California: Praeger, 2016), the authors also note how "beneficiaries" can be understood as integral to the paradigm of genocidal actors, comprising "perpetrators, bystanders, victims, rescuers, and beneficiaries," and also post-settler- colonial nations as "straightforward beneficiaries of genocide” (see 85 and 194).

71 Tatz and Higgins, The Magnitude, in particular Chapter Nine.

72 Nemes, 156.
} 
both from its collective past and its current present. In a climate in which Australia shows no compassion for those fleeing conflict and seeking better lives elsewhere, it would seem necessary to demonstrate to the Australian population what it is that asylum seekers and refugees flee from. The domestic prosecution of perpetrators of genocide and other state crime, including war crimes, would seem to serve this purpose. If a reason is needed beyond that criminal behaviour will be punished, across the globe, no matter where it was perpetrated, no matter to whom, and no matter how long ago, then I suggest we put this one forward. It may also help us face up to our genocidal past, and present. 